\title{
WHEN THE FUTURE IS EMOTIONLESS: SILAS'S STORY AND HOW EMOTIONAL "DISEASE" CHANGED HIS LIFE IN THE FILM EQUALS (2015)
}

\author{
Cut Novita Srikandi, Dzikra Ashri Asyifa, Imas Pratiwi, Rani Kholidaziya, Syifa \\ Maziyyatul Fikriyah
}

Faculty of Teacher Training and Education, The University of Muhammadiyah Tangerang

cutsrikandi@gmail.com, dzikraasyifa1999@gmail.com, Imaspratiwi1211@gmail.com, inarranikholid@gmail.com, Syifamaziie@gmail.com

\begin{abstract}
The world assumes that someone who has emotions is someone who will harm themselves and those around them. Emotions that are considered as a disease called S.O.S. (switched of the syndrome). This research aims to analyze a film entitled Equals (2015) that depicts a world with high technological advances and humans who do not have emotions. We will use the descriptive analysis method with Freud's psychoanalysis approach to analyze "Silas" as the main character who suddenly has an emotional feelings are forced to be hidden from the people around him including the woman he likes. There are three psychological structure of a person found in the psychology of literature that According to Sigmund Freud, namely the id, ego, and superego. The end result of this research we will see how Silas hides his feelings and find a solution about the situation. The story of Silas shows us about the emotional disease change his life in the future.
\end{abstract}

\section{Keywords:}

Emotions, disease, technology, psychoanalysis, feelings, film analysis, Equals 
Globish (An English-Indonesian journal for English, Education and Culture

Vol. 10, No.2, July 2021,

P-ISSN: 2301-9913, E-ISSN: 2597-9132

DOI: http://dx.doi.org/10.31000/globish.v7i2

\section{Introduction}

Humans are social creatures, adaptable creatures, creatures who communicate with the people around them every day. Every day there are events that will be experienced by humans and are also felt as feelings of sadness or joy, usually arise when an intense event occurs to us or to humans. Happiness always be around us, even though we only enjoy or see the event after our thoughts and feelings will respond to the incident, for example, happily getting something, being angry with someone, or more intensely we have a sense of love for someone.

On dramaturgical theory, which states using "impression management" to present ourselves to others as we expect to be perceived. Every situation is a new place, and individuals perform different roles depending on who is present (Goffman 1959). This theory explains that humans naturally act with what they are faced with, it is impossible for humans to respond differently to what they are faced with or not take any action.

It is proven that human emotions have existed since humans were born. It cannot be simply eliminated because of the mindset of humans every day are still changing. Thinking that everything must be more advanced than before. In any case humans must develop and think more advanced is similar in literary work for example film. The depiction of character in the film world very close with our life. That's why, by watching a film, the audience can also learn and analyze about human and emotion.

As a part of life, Literature is very close from a social reality. In this sense, life includes relationships between people, humans and events that occur in literary works. According to Rene Wellek and Austin Warren (Sariban, 2009), literature presents life that consists of a social reality. Literary works are also associated with imitation of the human's subjective world. In other words, literature is a reflection of human life.

In the world of literature, we can discuss emotional or other psychological languages. Literary psychology is a literary study that focuses on the psychological activity of both the characters in a literary work, the author who creates literary works, even the audience who enjoys the work, this theory is brought by Sigmund Freund who discusses literature in the psychological side (Aras, 2015). There are many literary 
Globish (An English-Indonesian journal for English, Education and Culture

Vol. 10, No.2, July 2021,

P-ISSN: 2301-9913, E-ISSN: 2597-9132

DOI: http://dx.doi.org/10.31000/globish.v7i2

works that discuss psychology. Whereas, in this research, we use film as our subject of the study. We focus on the main character of the film to explore about psychoanalysis in thr literary work.

Equals (2015) is a Hollywood science-fiction romantic drama film, directed by Drake Doremus, written by Nathan Parker, starring famous stars such as Nicholas Hoult and Kristen Stewart as Silas and Nia. They live in a dystopian world where people have no emotions. They live regularly with technology side by side with very high technology. For those who live in a very high civilization, chatting with each other is taboo or rarely found. They become individual and only focus on pleasure of themselves. Living with high technology and pleasure of themselves, make them have to get rid of their emotional feelings. In that world, if there have emotional feelings, you will harm yourself and considered it as disease. Finally, there are two peoples who are caught having an intense relationship with two opposites sex, so they must be put in a cage for isolation.

An illustrator named Silas (Nicholas Hoult) infected with the disease was forced to make him alienated from the environment there, on the one hand, his coworker Nia (Kristen Stewart) was actually also infected, Silas who knew Nia had been hiding the symptoms of the disease for a long time tried to approach. As a result the two of them grew closer, and something happened inside of them. The rules that exist in their environment cannot be denied, Silas and Nia realize that they are in love with each other.

This film tends to focus on human psychology that is abolished, how can someone who has feelings be called a disease and must be exiled. The film entitled Equals (2015) uses a psychological approach to conduct this research. In this study, we understands that human emossion and personality are natural things. It doesn't matter when it has to be experienced by humans, thinking must show emotions. The film shows us how someone who commits suicide because experience stress due to having to hold back his emotions. Therefore, we will find the answer of our problem of the main character in this film using Psychology Sigmund Freud. He said that behavior is determined by the subconscious which contains its nature. 
Globish (An English-Indonesian journal for English, Education and Culture

Vol. 10, No.2, July 2021,

P-ISSN: 2301-9913, E-ISSN: 2597-9132

DOI: http://dx.doi.org/10.31000/globish.v7i2

\section{Theoritical Framework}

In this study, researchers used the theory of Freudian criticism about the iceberg theory. Based on the work of Sigmund Freud (1856-1939). The iceberg theory in psychology was first coined by the father of psychology, namely Sigmund Freud, he used the parable of this iceberg to explain his theory of the human mind. He likens the visible top of the iceberg to the conscious mind. While under the conscious mind there is a part called the subconscious mind (subconscious mind), as well as the largest part of the mountain which is located at the bottom that is not visible. This is what is then called the unconscious mind.

In the Iceberg theory of Psychology Sigmund Freud said that behavior is determined by the subconscious which contains instincts or natural instincts and human biological drives. Psychological conditions that are not always visible by Freud are divided into three consciousness of human consciousness, namely: conscious (conscious), preconscious (preconscious), unconscious (unconscious).

\section{Conscious Mind}

According to Freud, the conscious mind is the represent of perceptions, memories, thoughts, and feelings. It exists as the tip of the iceberg. We can see the existence of conscious in our eyes, and it's something that we actually shown in front of the people.

\section{Preconscious Mind}

Under this conscious mind, a preconscious mind carries our memories. From this preconscious mind, a person can recover memories into the conscious mind. In the other words, preconscious mind is a bridge to the conscious mind. In this case we can take an example from dreaming. Dreaming is the thing that represent the preconscious mind, because dreaming is the mixed by our memories and something that we actually doing in daily.

3. Unconscious Mind 
Globish (An English-Indonesian journal for English, Education and Culture

Vol. 10, No.2, July 2021,

P-ISSN: 2301-9913, E-ISSN: 2597-9132

DOI: http://dx.doi.org/10.31000/globish.v7i2

If conscious is a mind that we can see, and preconscious is something under it, unconscious mind is the larger part under all of it. All the things, which are not easily available at a conscious level, example like our instincts, our memories, emotions, or even trauma. Like an iceberg, the unconscious is the deepest and important part of the personality. It plays as the real us.

From the three elements that represent people mind above that explained about conscious mind, preconscious mind, and unconscious mind, we will comparing it with the film Equals (2015) and we will analyze the conscious mind, preconscious mind, and unconscious mind from the main character Silas.

\section{Research Methodology}

Research methods or research methods derived from English. The method comes from the word method, which means the science that is explained by methods or ways. The word research is a translation of the English word "research" which consists of the words re (repeat) and search (search, pursuit, search, and investigation). Research means conducting searches related to certain problems to be processed, analyzed, drawn conclusions and then look for solutions (Bachtiar, 1999). We can understand that the meaning of research methods is about scientific observations to find, compile reports based on the results of research methodologies.

Bogdan and Taylor (1975) said that Qualitative method as a research procedure that produces a description of the data in the form of words or verbal from the people and observed behavior. Creswell (2014) defines qualitative research as research that is used to examine human and social problems. Where the researcher will report the results of the study based on the view of the data and analysis of the data obtained in the field, then described in the research report in detailThis study uses an approach and the type of research is descriptive (qualitative descriptive). A qualitative approach is carried out using descriptive analysis to be able to describe the facts in the film Equals (2015). The researcher observes and analyzes the film in order to be able to describe the psychological values that exist about the life of the main character (Silas). 
Globish (An English-Indonesian journal for English, Education and Culture

Vol. 10, No.2, July 2021,

P-ISSN: 2301-9913, E-ISSN: 2597-9132

DOI: http://dx.doi.org/10.31000/globish.v7i2

Data collection is done by observing, understanding, and viewing the film being studied Equals (2015), by capturing the scene, taking pictures from the film, besides that the researcher reads carefully the information about the film Equals (2015). By watching the film Equals (2015) an overview of the story, especially about character descriptions can be collected. Then the researcher looks for sentences that contain information about the characters in the film and then captures them. After the data is collected, the researcher sorts out which items are important, the information is used as supporting evidence in this research.

\section{Result and Discussion}

Research on the film "Equals (2015)" focuses on the main characters, namely Silas and Nia. Freud's psychoanalytic approach used in researching the main character. In this section we will discuss films with the Ice Berg Theory by Sigmund Freud. We divided the analysis into 3 parts, conscious, preconscious, and unconscious.

This film tells the story of men and women who live in an advanced civilized society. Who would have thought that having emotions and feelings is a disease. The film begins with the activities of the main character named Silas. His life is organized or has been programmed in a collective society. Silas lives in an advanced civilization, working as an illustrator at a company called Ethmos.

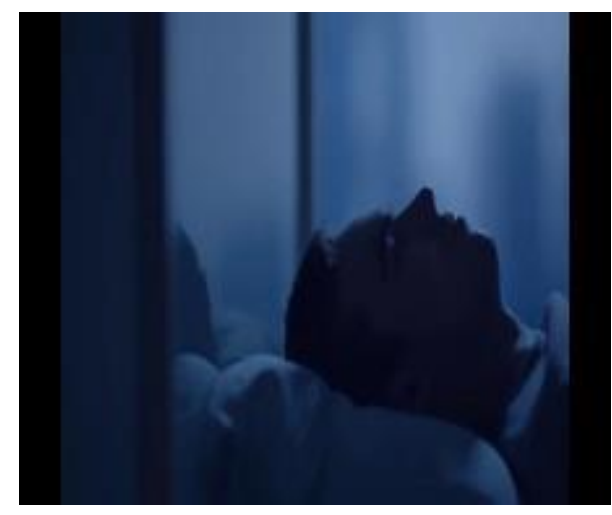

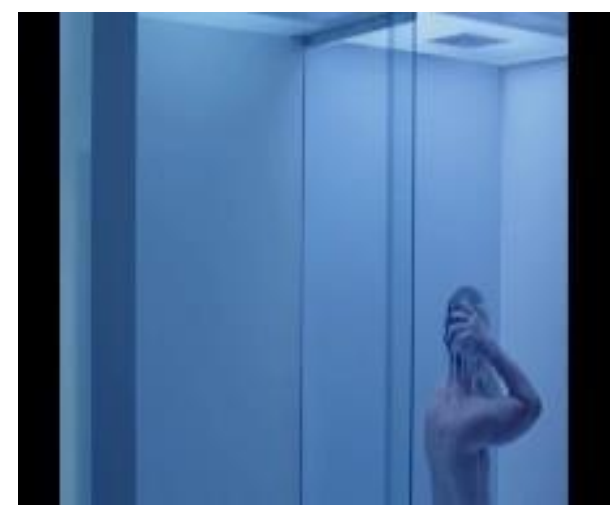

2 


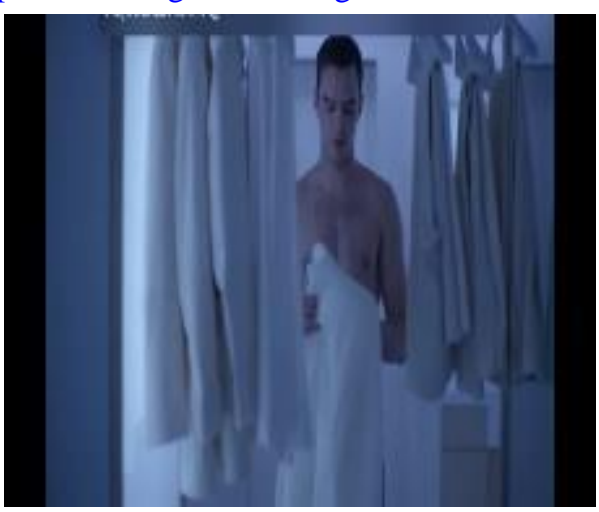

3

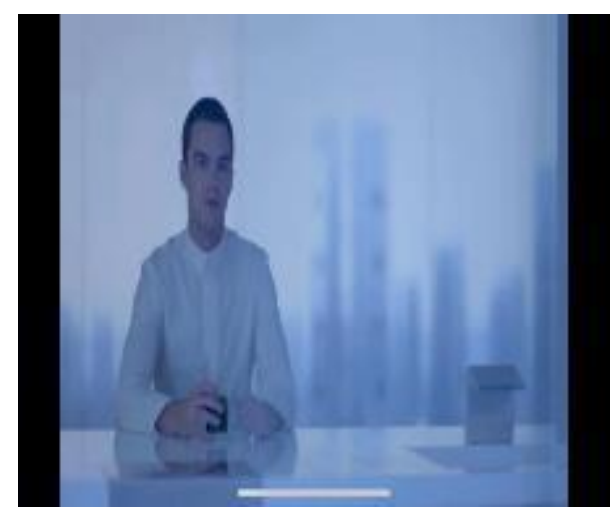

4

Illustration I (0:00-1:34)

The pictures above show the initial scene which is an activity that Silas do every day. In the first picture, Silas looks like just woke up. The second picture Silas take a shower, and after that Silas wear his clothes and prepare to get ready to go to the Ethmos and the last picture Silas seen drinking a cup of coffee. The scene show at the beginning told us that Silas's daily activities like this were habitual action as it has been programmed.

\section{a. Conscious of Silas}

Since birth emotions and feelings have been turned off to allow humans to live individually or alone and only focus on the good and progress of society. Those who start to feel emotions and feelings are considered to be affected by Switch on Syndrome (S.O.S). All people think this disease is not contagious but is enough to disturb life and the environment. For them advanced society has emotions and feelings, chatting and gathering is one of the defect that primitive people have in their past. 


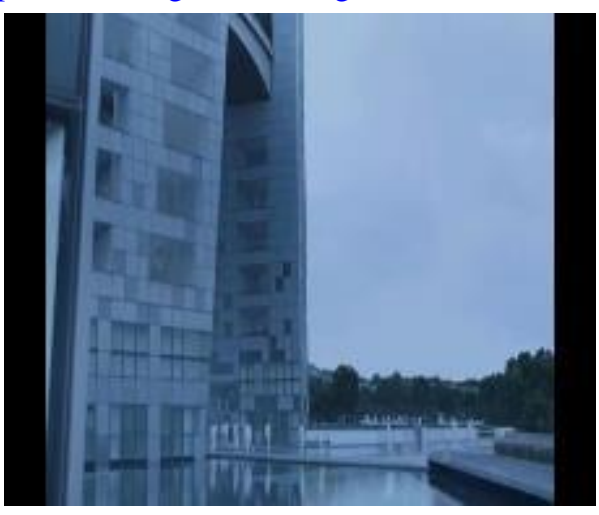

1

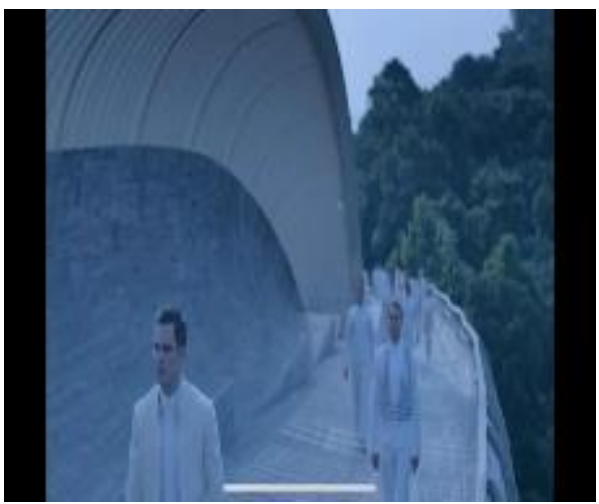

3

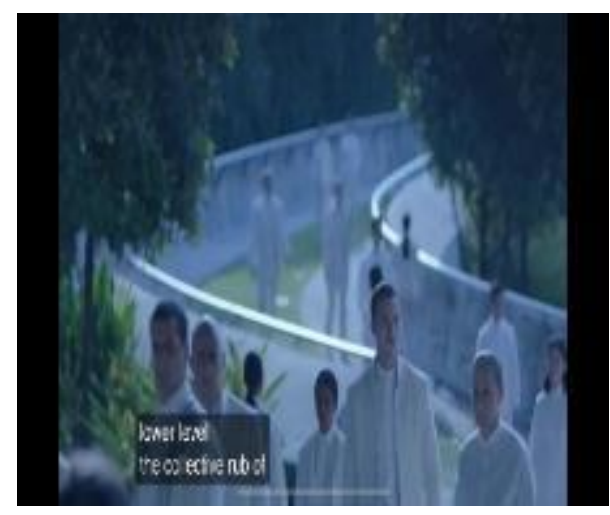

2

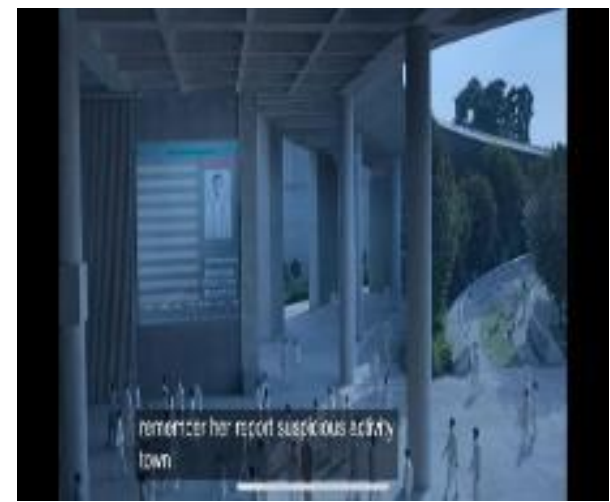

4

Illustration II (1:42-2:07)

The pictures above are several scenes of the progress of the world at this time, a world without emotions. The people there are known "Equals" who lives under the collective legislative that monitors the citizen actions. Silas works every day, same like any other collective society, living with discipline, devoid of emotions and feelings and this is a very normal thing in a collective society.

Nia is one of Silas's friends at the Ethmos Company but in a different division with him. One day there was a suicide by jumping from the top of the building while they were working. When everyone saw the suicide on the same occasion Silas saw that there was something different with Nia. Nia showed her anxiety and emotions none known Nia hid it but Silas found out. 


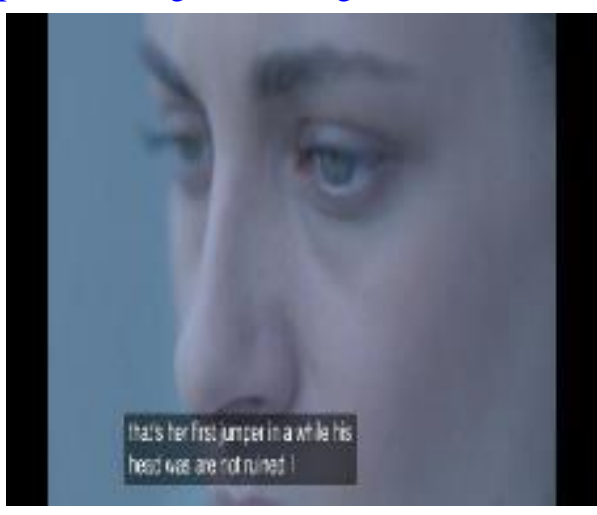

1

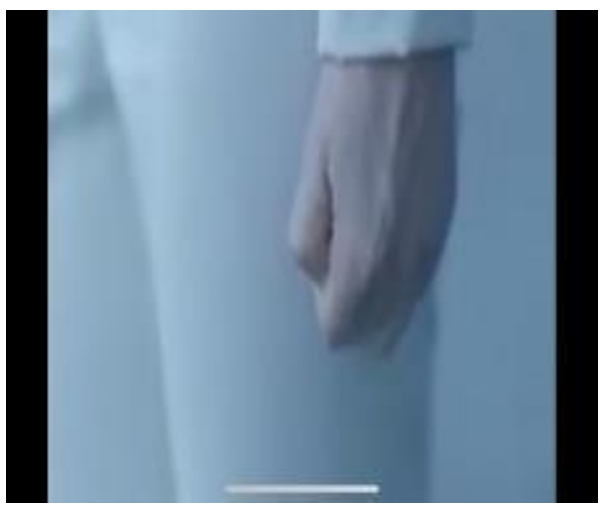

3

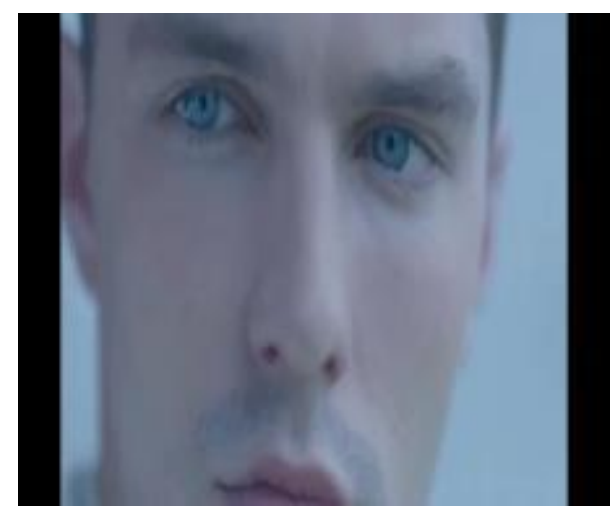

2

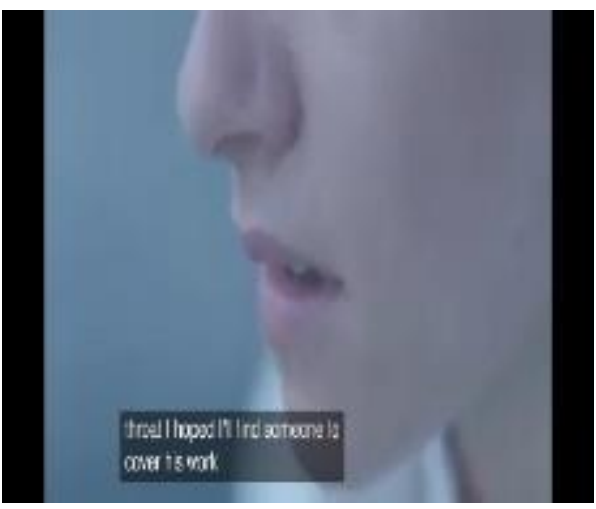

4

Illustration III (8:37-8:51)

The pictures above are scenes where they are all watching suicide by jumping from the top of the building, Nia looks very scared and leaves the place. Silas notices that Nia has emotions and feelings. Since Silas realized that Nia was feeling emotions, he paid more attention to Nia. Even though about Nia continuously, Silas always followed Nia everywhere until Silas feel interested in Nia.

\section{b. Preconscious of Silas}

Silas live his day as usual, but now he keeps receiving the information about S.O.S. (Switch on Syndrome). He knows that he is one of people who have that disease. In his daily life now, Silas notices that something completely different from before. And the thing that he noticed is:

1. His sense of taste is getting sharper. 
Globish (An English-Indonesian journal for English, Education and Culture

Vol. 10, No.2, July 2021,

P-ISSN: 2301-9913, E-ISSN: 2597-9132

DOI: http://dx.doi.org/10.31000/globish.v7i2

When he scanned his identity before working, when he began his work, and even when he went home, he always got the information about S.O.S by the computer. He noticed that he must avoid physical contact, touching, and emotions, because it's a sign that someone has a S.O.S. (minute 07:40). And when he had home and have a dinner, he noticed that the taste of the food is different, even though it's exactly the same food that he usually had before. Here is the scene where he feels the difference in taste in his food.

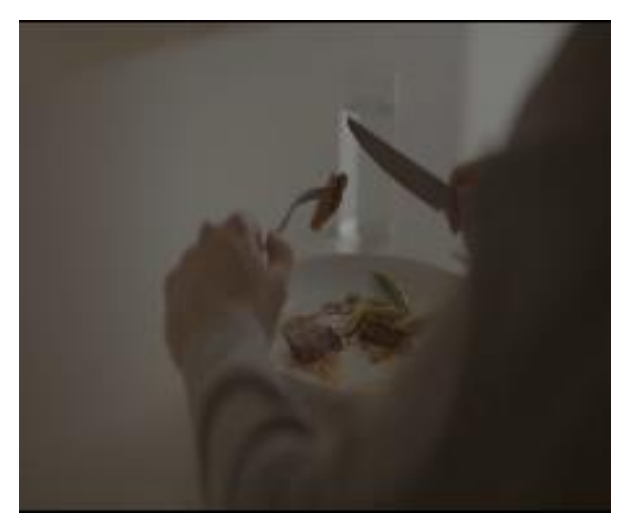

1

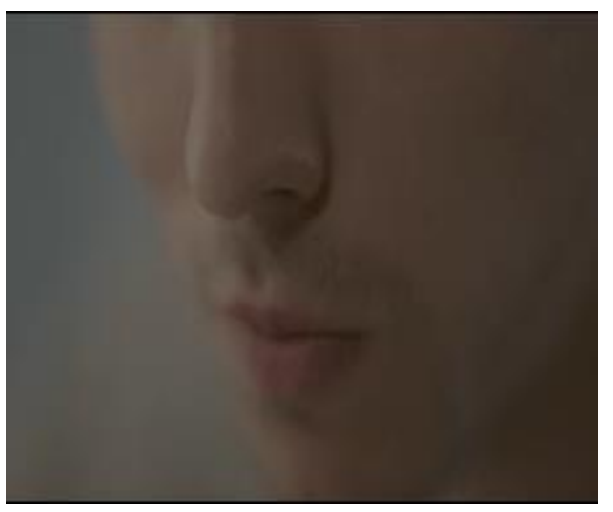

3

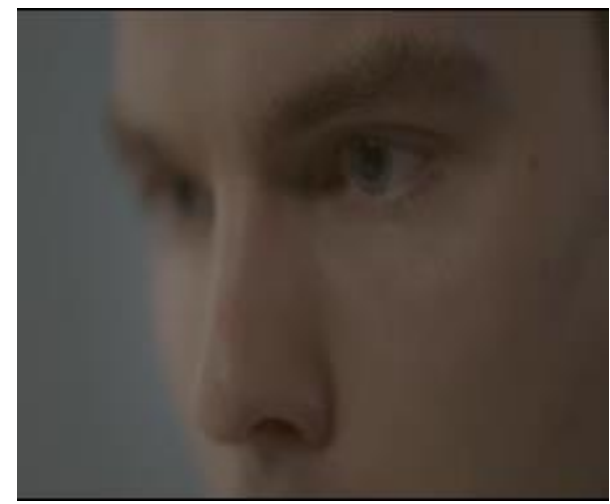

2

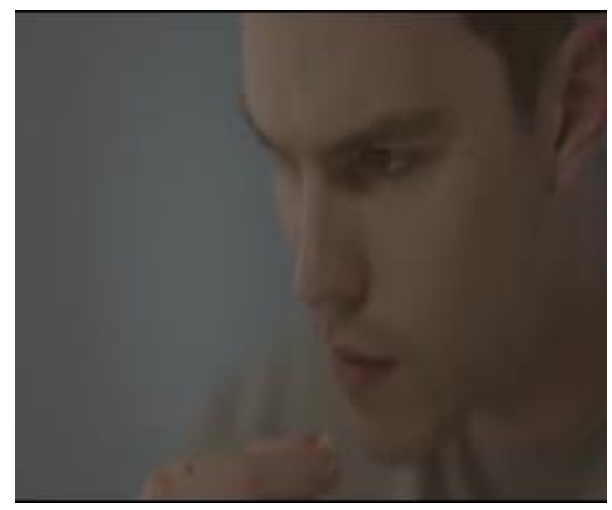

4

Illustration IV (10:01-10:27)

The picture above is the sequence of events that occurred in the scene when Silas's sense of taste is getting sharpen. From the first picture, he start to eat and his eyes on the picture 2 clearly represent his shock about the taste of the food that amazingly different than before. In the picture 3 he felt it on his 
Globish (An English-Indonesian journal for English, Education and Culture

Vol. 10, No.2, July 2021,

P-ISSN: 2301-9913, E-ISSN: 2597-9132

DOI: http://dx.doi.org/10.31000/globish.v7i2

mouth and he continue make sure in picture 4 . He can taste the food more lightly than before he got the S.O.S.

2. His sense of touch is getting more sensitive.

In addition to his increasing sense of taste, his sense of touch is also increasingly sensitive. S.O.S is not only about emotions, it's also about sensitivity, especially in touching. In this scene below, Silas feels that only touch his hand, it feels different from before.

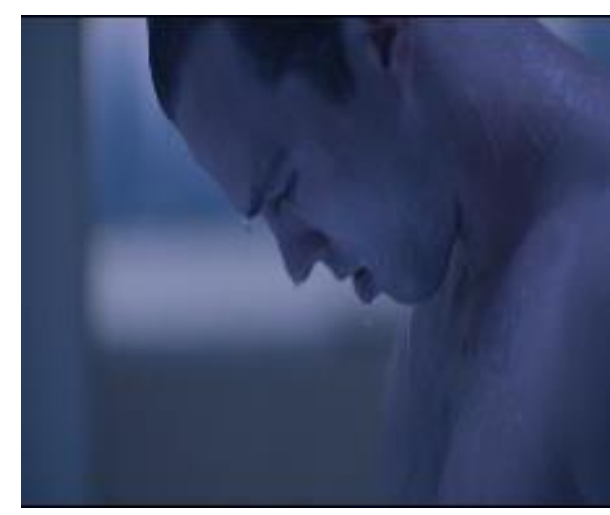

1

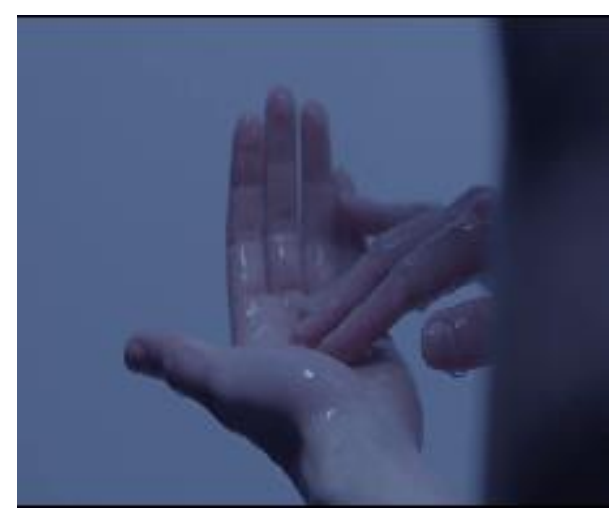

2

Illustration V (10:50-11:15)

The picture above is the sequence of events that occurred in the scene when Silas's sense of taste is getting more sensitive. He can feel the water dropped into his body, he can feel more lightly when he touched his hand. He feels so strange when he experienced that thing because he has never been feels before, clearly seen by his face.

3. He lost his focus.

In his daily working, he is good and full of focus before. But after he knows that he has S.O.S., he lost his focus. He still secretly looking for Nia and didn't pay attention to his meeting, as shown by the scene below. 


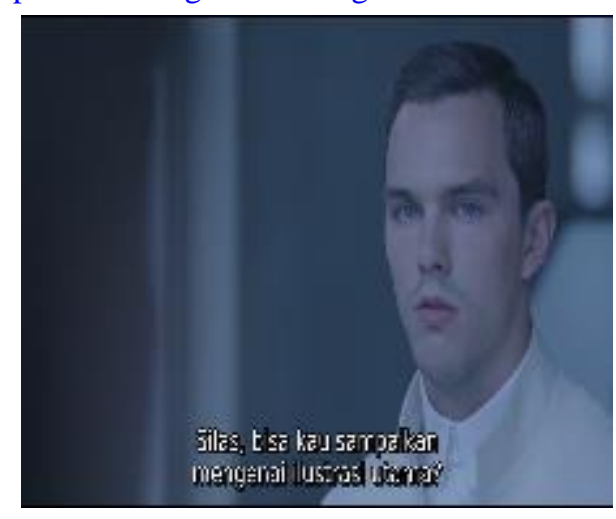

1

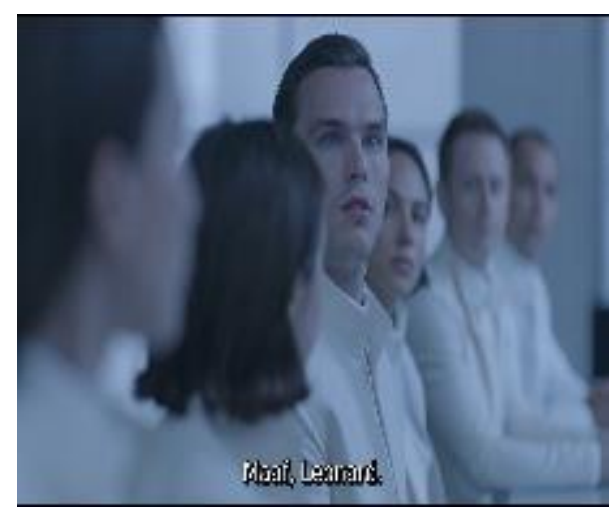

2

\section{Illustration VI (11:16-11:44)}

The picture above is the sequence of events that occurred in the scene when Silas lost his focused and only focused on Nia. Clearly seen on the scene when he said, "Sorry, Leonard", a sign that he is not focused on the meeting. In the other chance he also looking for Nia and secretly looking at her body part like eyes, lips, and every movement she make.

4. He had a dream.

Silas had never experience dream before. He doing his live very flat and organized, so do everyone. When he has S.O.S., for the first time, he had a dream. He's so confused about the feeling when he got a dream, and unfortunately it's a bad dream. In his dream, he is standing on the top of building, looking down to the ground, ready to jump.

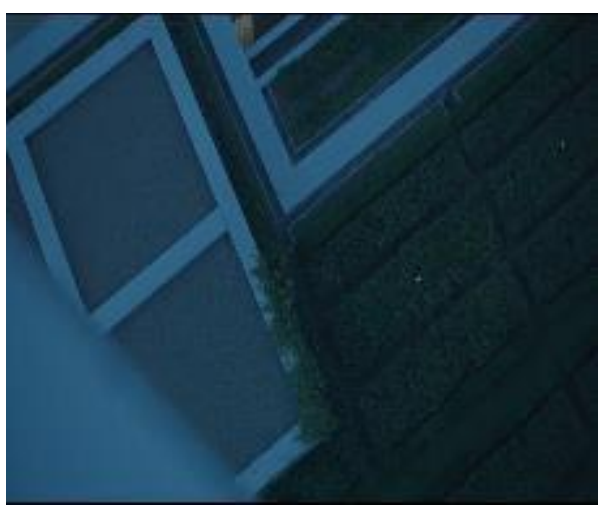

1

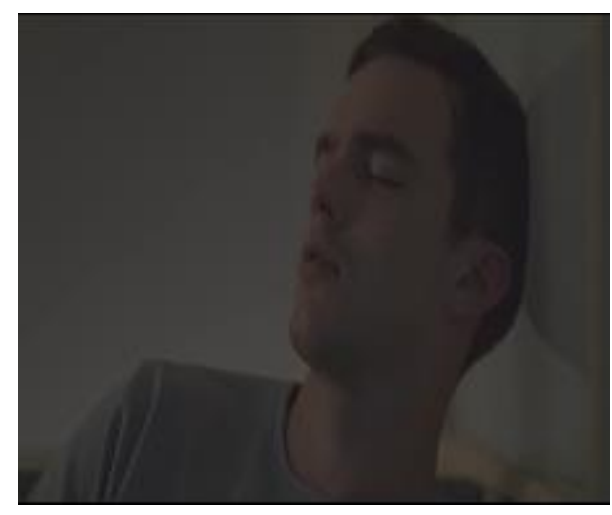

2 


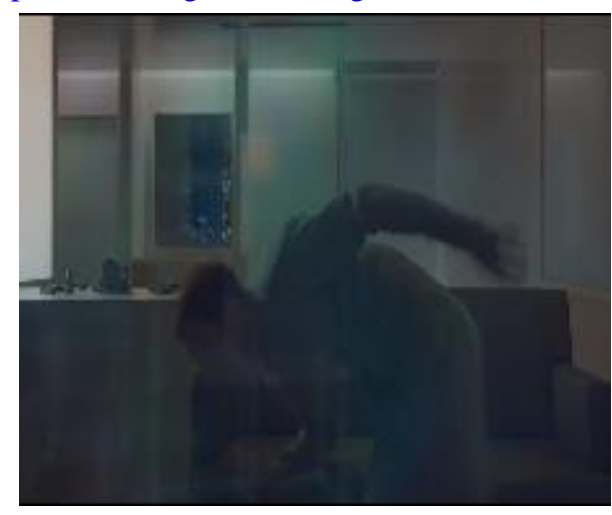

3

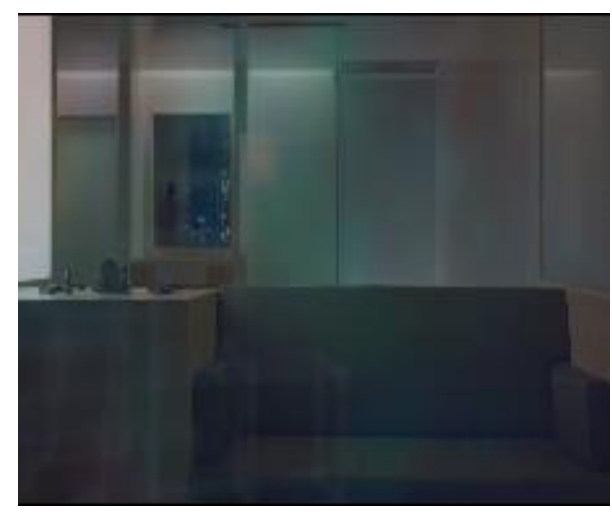

4

Illustration VII (11:56-12:28)

He hurt himself because of shocking (picture 4), he is bumped his head into the wall and get injured. Silas, who never had a dream before, for the first time experienced it and it makes him so confused about what happen with his body. He has so many questions on his mind about how if this "disease" is getting worst and maybe he will be taken to the "cage".

Everything that Silas felt he kept it quietly and without anyone knowing it except for the dream. He barely ask the doctor about what exactly it was (minutes 14:16), and the doctor said it was a nightmare. Now Silas feels more strangely and afraid because of this "disease", clearly seen on his confused and afraid face.

\section{c. Unconscious of Silas}

Day by day Silas starts to get used to his condition. He takes his medicine, and follow the instruction by the computer says. His interest in Nia is also increasingly high. He knows that Nia is also had S.O.S., but she clearly hide it perfectly.

In his working live, Silas is trying to get closed to Nia more than before. He keeps looking at her, he keeps following her, and he keeps trying to have conversation with Nia. And when he can make it, he is always looking at Nia in detail. It can see in the scene below. 


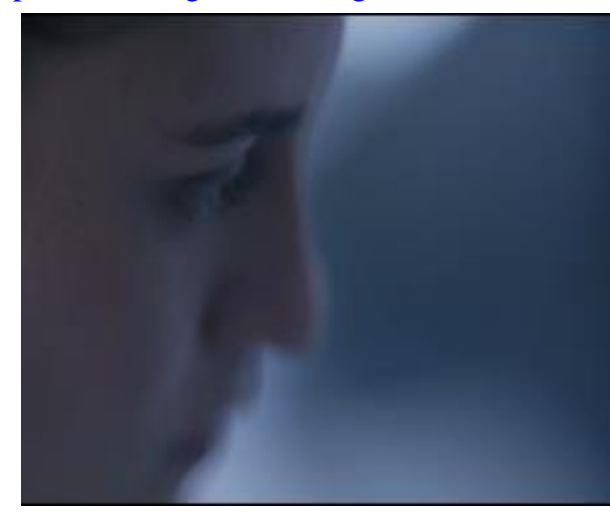

1

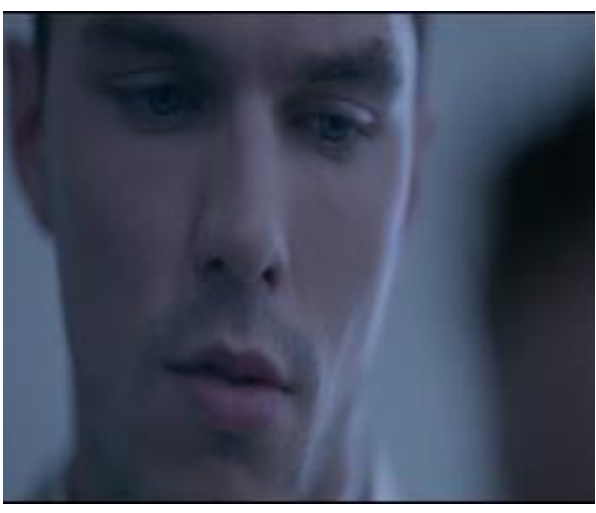

3

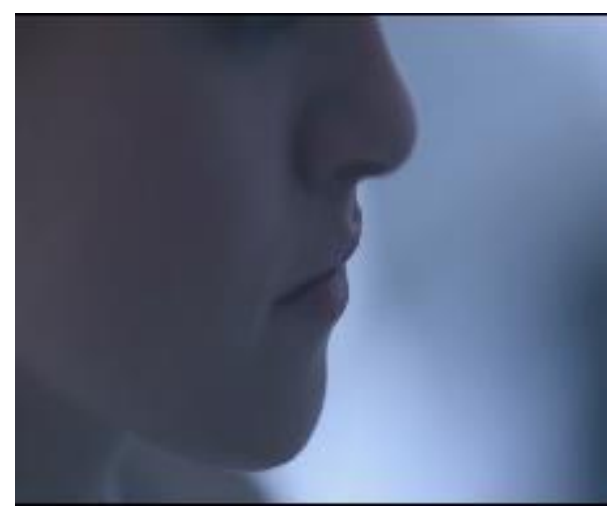

2

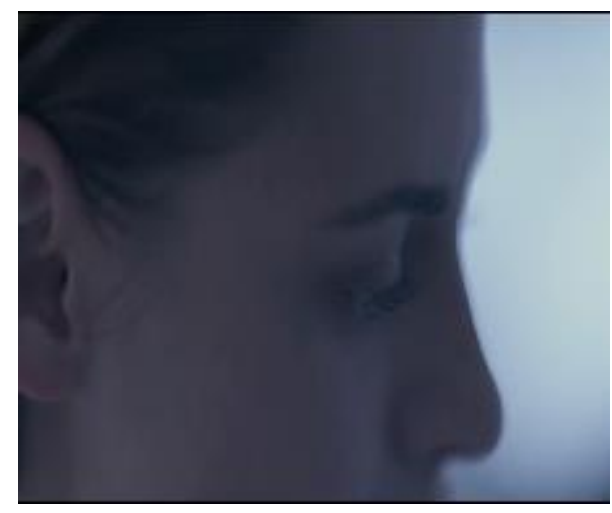

4

Illustration VIII (22:37-23:40)

Love is when you can't even look at the other, just look at the one that you loved is the represent of what Silas's feels on Nia right now. S.O.S. is giving him a thing that we called "love". He can't deny the beauty of Nia and he even changed the position of his job to the same job as Nia. In the same scene, Silas said, "I switch with Leonard". He's clearly change his position of job same with Nia because he wanted to see Nia more and close to him. His curiosity of Nia is getting higher and higher. In the night, he enter his office and see Nia's monitor only to heard the recorded of Nia's speech. He saved it on his mind and replied it again and again on his mind.

S.O.S makes the sufferer become hopeless and need something to release the emotions. As mention before, couple is a danger in S.O.S. They must 
Globish (An English-Indonesian journal for English, Education and Culture

Vol. 10, No.2, July 2021,

P-ISSN: 2301-9913, E-ISSN: 2597-9132

DOI: http://dx.doi.org/10.31000/globish.v7i2

avoid physical contact, touching, and emotions. But apparently, S.O.S. makes the sufferer feel thirsty about that.

Nia has S.O.S., but she won't do appointment to the doctor, it's what Silas's thought about Nia when he seen Nia shown her emotions in the beginning of the film. This is why he is curious about Nia and end up falling in love to her, without realizing it is love, until that night. Silas and Nia now in the same division, and in the night when there's only two of them, Silas takes this moment to get closed to Nia.

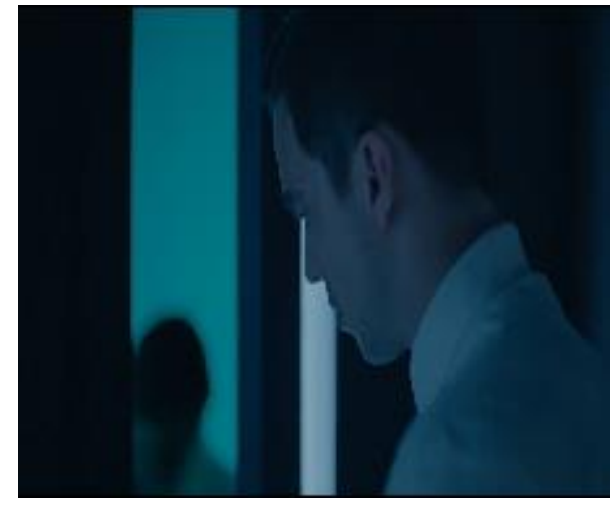

1

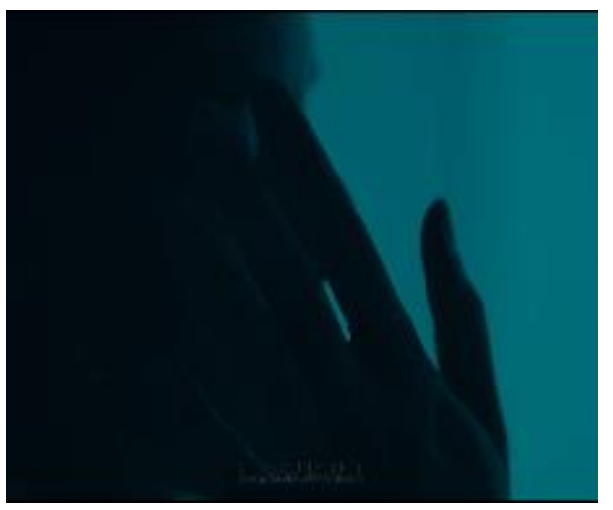

3

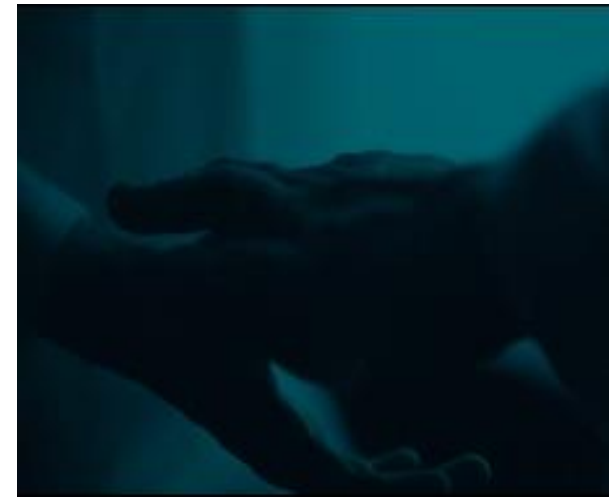

2

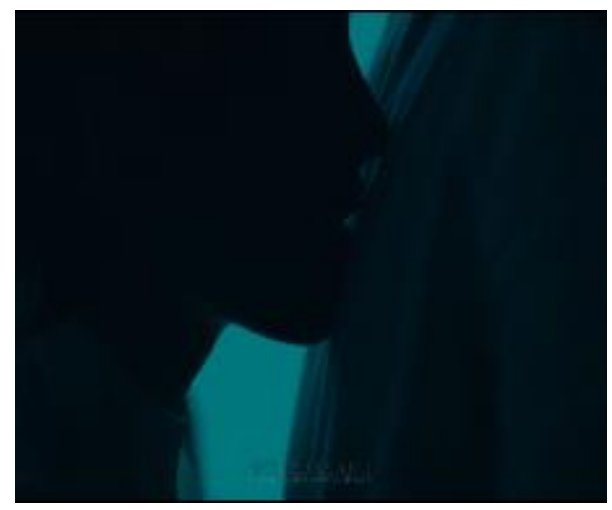

4

Illustration IX (31:47-33:21)

In the picture 1 , Silas followed Nia to the rest room and he looked at Nia who look hopeless. In the picture 2, he tried to touch Nia event he know that touching is something that he must avoid because he have a S.O.S., in picture 3 surprisingly Nia respond all the touch by Silas and the in the picture 4 she is lean his head on Silas's chest, and they hugging. Nia confess about her 
Globish (An English-Indonesian journal for English, Education and Culture

Vol. 10, No.2, July 2021,

P-ISSN: 2301-9913, E-ISSN: 2597-9132

DOI: http://dx.doi.org/10.31000/globish.v7i2

having S.O.S. for more than 1 year and she's not taking medicine because she's afraid of the "cage" and death penalty.

Silas trying to comfort Nia like a good man. He feels the comfortable when Nia on his side. And then, they start to touching and kissing, like the actual couple who fall in love deeply. Only in one scene, Nia's feeling is completely changing from pretending not caring to someone who being honest with all the feelings.

Silas and Nia's life is completely changing since they're honest with their feelings. Silas not take the medicine again. And like the actual couple, everyday Nia will sleep on Silas's room and they take their time together. They touching, kissing, make out all night long. In the daylight, they seem like normal partner, but in the night they are an actual couple who loved each other. In the night when they talked together, they talked about how to escape from Ethmos, to have their live freely and happily.

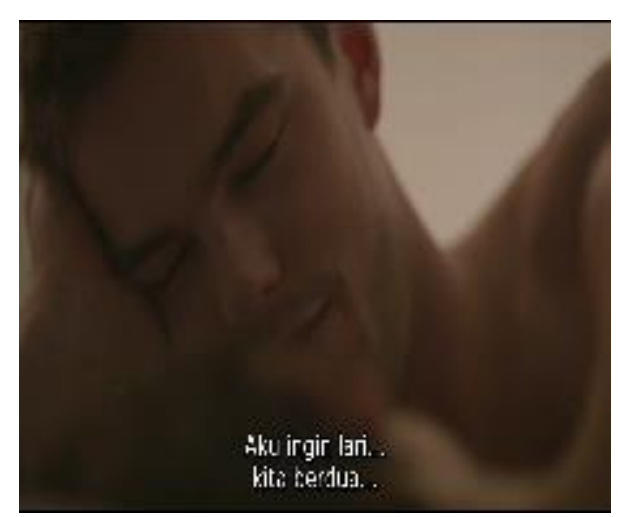

1

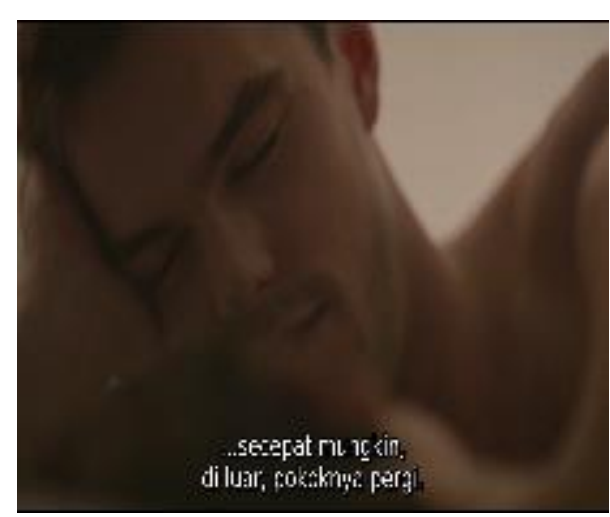

2

Illustration X (59:44-1:00:53)

They like the bird who want to escape from the cage, it seems like they have a plan to life outside together, so they can expressed their emotions more. And with all of that big plan, they discuss about the plan with their friends who also lived same as Nia (not consume a medicine).

Silas and Nia have their life happily with touching and sharing emotions each other. They also have a big plan to escape from Ethmos, with all of the 
Globish (An English-Indonesian journal for English, Education and Culture

Vol. 10, No.2, July 2021,

P-ISSN: 2301-9913, E-ISSN: 2597-9132

DOI: http://dx.doi.org/10.31000/globish.v7i2

suggest from their friends and all the consequences if they escape, they still want to be there. They realized that Ethmos is holding back their happiness.

"S.O.S is not even a disease. That's what they said, but pushing our gen, that's what they done between fertilization and birth. S.O.S is the way we are and inhibitor is only what they done to disappear it." (Scene in minutes 55:21).

In the way of they plan to escape, the cure of S.O.S. is updated.

"It's the cure that restores health and systematic orders to the individuals. With the Ashby ENI cure, it's only a matter of time for all current S.O.S. cases are treated, and future case is prevented. The ENI cures injected directly into the neck, leaving a small coin like scar, a quickly simple procedure. Once it done, the drug needs a six hours to absorbed, before the disease is completely neutralized. It's regardless of stadium, the patient will be back normally." (Scene in minutes 1:03:43).

Nia got panicked by that information, and she begin to angry, crying, and have a high emotional. What she knows about having an emotional it's only happiness before, but now it seems like it turn to the bad side. In the same of time, Silas is trying to make Nia calm and their plan is still going, they still have to escape from the Ethmos.

In the other hand, the cured is constantly shared to all of the patient, and Nia is suspected as one of the patient. She got to the doctor and ready for the result that she has S.O.S., but the doctor got shocked. Nia is pregnant.

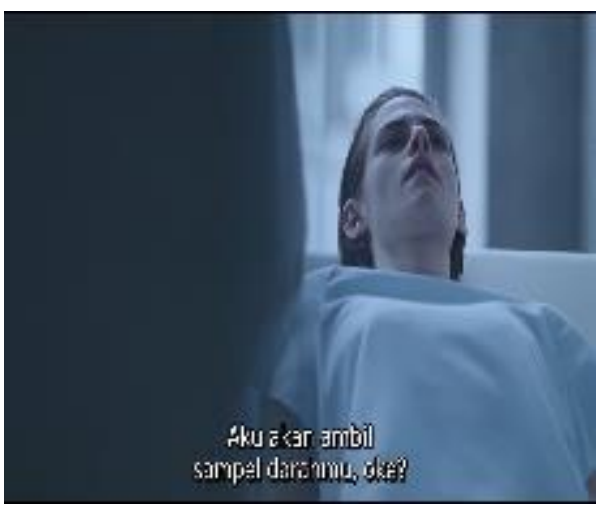

1

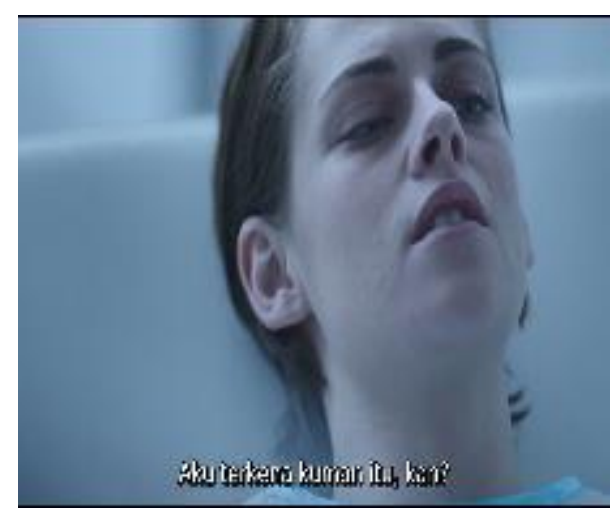

2 


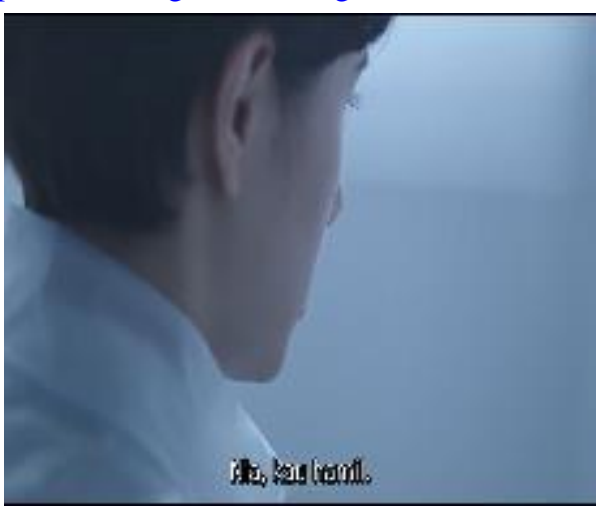

3

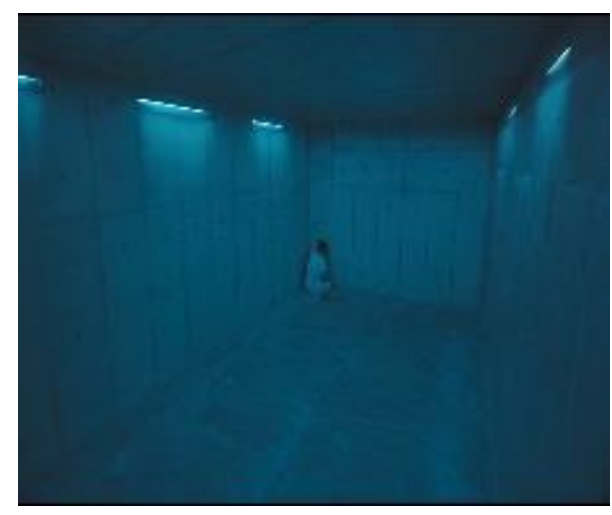

4

Illustration XI (01:12:11-01:14:11)

Pregnant is one of the big offense in Ethmos because when you pregnant, automatically you have done all the things that you have to avoid for not infected to S.O.S. Nia is pregnant and she automatically send to the "cage". The plan is ruined in the second of time.

Silas, who is afraid to Nia tried to search Nia in all of the way, but he got the information from one of his friend that Nia is pregnant and sent to the cage. He's so depression and he almost deciding to suicide.

Silas though that Nia was dead, and almost deciding to suicide. In the other scene, Nia is switch data to the woman who suicide in the cage so her data will turn into that woman and she can escape from the cage. The hopeless Silas then deciding to take the cure because he though that Nia was already dead.

Nia is waiting in Silas room, and Silas back with the scar on his neck, sign that he's already take the cure. Nia is trying to make Silas fight with his feeling and try to remember all the things that they do together. The plan to leave Ethmos is getting close, they still doing that plan. 


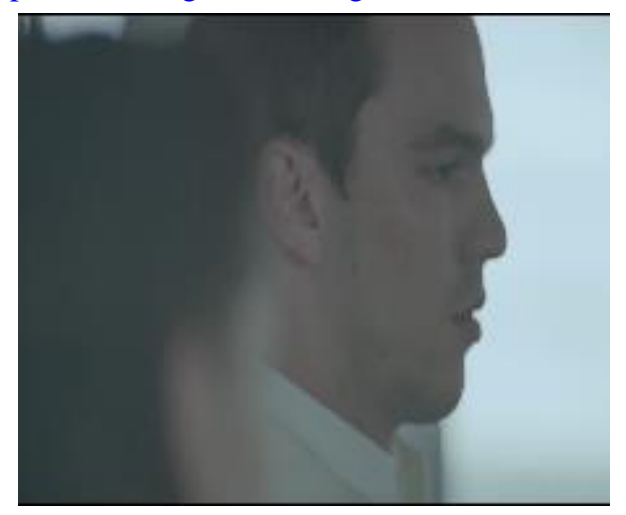

1

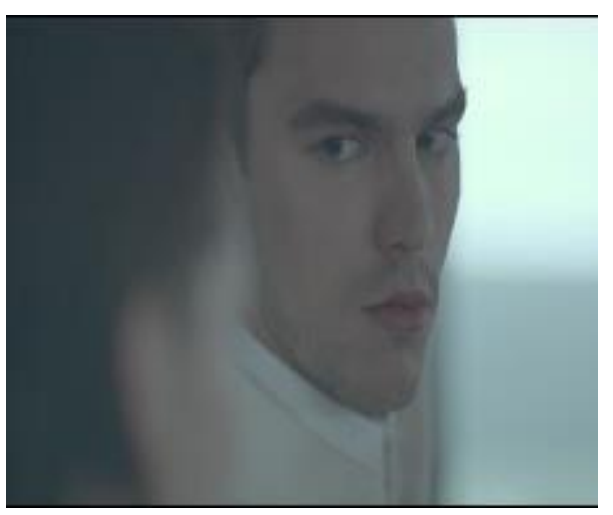

3

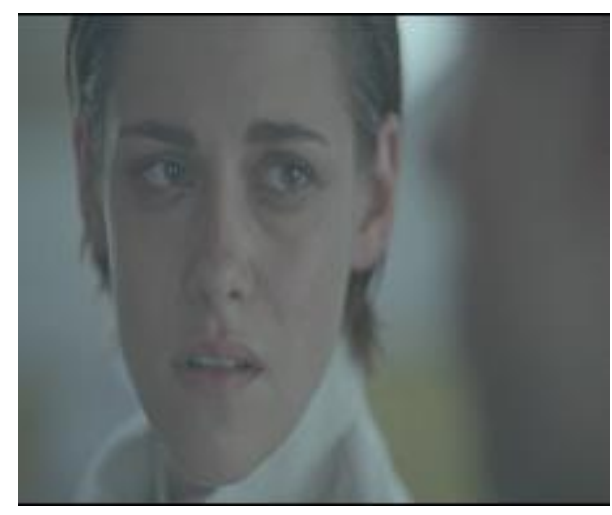

2

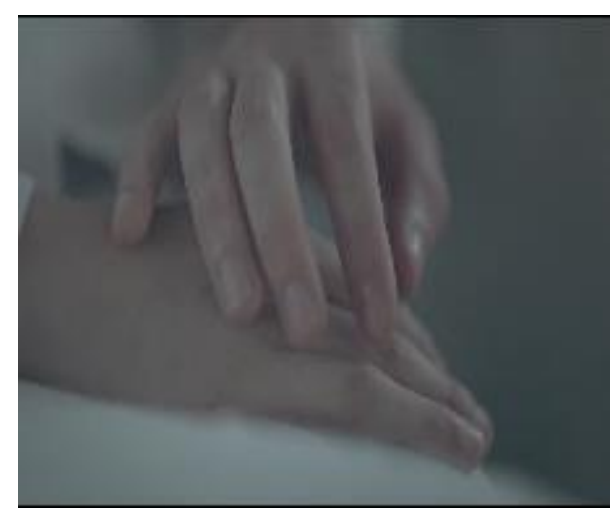

4

Illustration XII (1:32:53-1:33:54)

With the "cured" Silas and the sad Nia, with Silas who's still fighting with his feelings, and Nia with all the loved she have to Silas, they leaving the Ethmos and trying to have their live together outside the Ethmos.

\section{Conclusion}

Equalss is a romantic film directed by Drake Doremus.Released in 2015, the film stars Nicholas Hoult, Kristen Stewart and Vernetta Lopez. Equalss tells the story of a man named Silas who lives in a world without love and emotion.

The film Equalss itself tells the story of a futuristic world without emotions in it. Kristen and Nicholas play the role of lovers who love each other. Intimacy between the two is strictly prohibited by society. This situation forced them to flee. In this film, anyone who feels emotions and feelings of love is a disorder and a disability and must 
Globish (An English-Indonesian journal for English, Education and Culture

Vol. 10, No.2, July 2021,

P-ISSN: 2301-9913, E-ISSN: 2597-9132

DOI: http://dx.doi.org/10.31000/globish.v7i2

be healed. Whoever is caught having a relationship between the opposite sex will be locked in a cage (isolated).

Silas (Nicholas) is a handsome man and of course no partner. In the world of Equalss, there is no love. Especially when you get married and have a kids. For those who feel emotions in their lives, they are sentenced to have SOS disease, and it must be removed. Women at a certain age (and of course free of SOS disease) will get a call from the government to be fertilized with technology developed by experts. Meanwhile, men are destined to work to build the nation until they die. So did Silas. He works as an illustrator, at the technology-based company, Ethmos.

\section{References}

Aras, Gokses. (2015). Personality and Individual Differences: Literature and Psychology - Psychology in Literature in Third World Conference on Psychology. Ankara: Elsevier.

Goffman, E.(1959)The Presentation of the Self In Everyday Life. New York: Doubleday .

Bogdan, Taylor. (1975). Metodologi Penelitian Kualitatif. Bandung: Remadja Karya

Creswell, J. W. 2014. Research Design: Qualitative, Quantitative and Mixed Methods Approaches: Fourth edition. Thousand Oaks, CA: Sage Publications.

Freud, S. (1900). The Interpretation of Dreams. Standard Edition, vols. IV-V. London: Hogarth.

Freud, S. (1923). The ego and the id. Standard Edition, vol. XIX. London: Hogarth. Freud, S. (1933). New introductory lectures on psycho-analysis. Standard Edition, vol. XXII. London: Hogarth.

Freud, Sigmund. An Outline of Psychoanalysis. London: The Hogarth Press, 1949. 
Globish (An English-Indonesian journal for English, Education and Culture

Vol. 10, No.2, July 2021,

P-ISSN: 2301-9913, E-ISSN: 2597-9132

DOI: http://dx.doi.org/10.31000/globish.v7i2

Pruss, M, Diggins, C, Ruark, A, Schaefer, M, Stern, J. (Producers). (2015). Equals.

A24, DirecTV Cinema: USA.

Rene Wellek dan Austin Warren. (1989). Teori Kesusastraan. Jakarta: Gramedia.

Rivai, B. (1999). Psychologi Pendidikan. Jakarta: Bina cipta

Sariban. (2009). Teori dan Penerapan Penelitian Sastra. Surabaya: Lentera Cendikia. 